Novel study of trace elements

\title{
Study of trace elements in BioArena system and
} in in vivo conditions

\section{Ernő Tyihák ${ }^{1}$, Ágnes M. Móricz ${ }^{1}$, Péter G. Ott ${ }^{1}$, and Emil Mincsovics ${ }^{2}$}

1) Hungarian Academy of Sciences, Centre for Agricultural Research, Plant Protection Institute, Budapest, POB 102, H-1525 Hungary

2) Corvinus University, Faculty of Horticultural Sciences, Department of Genetics and Plant Breeding, Budapest, Hungary

\footnotetext{
Abstract: The adsorbent layer system is especially suitable for the biological evaluation of different compounds and trace elements as well. Present experiments showed that formaldehyde (HCHO) molecules participate in the antibiotic activity of $\mathrm{Cu}$ (II) ion, an „old antibiotic". The elimination of $\mathrm{HCHO}$ from the chromatographic spots (e.g. by reduction or capturing) resulted in a characteristic decrease of the antibiotic effect of trace elements. The trace elements are $\mathrm{HCHO}$ carriers and generate a double effect (first step: deprivation of $\mathrm{HCHO}$ as also biological effect; second step: release of $\mathrm{HCHO}$ with big killing activity). These features offer good opportunities for influencing fundamental biochemical pathways. It has been established that the trace elements (mainly transition metal ions as e.g. $\mathrm{Ni}$ (II) ion) always generate quadruple, bioequivalent, specific immune-stimulating activity in plants with
} 
a non-linear dose-response. $\mathrm{HCHO}$ and its reaction products (mainly $\mathrm{O}_{3}$ ) are responsible also for this latter activity.

Key Words: antibiotic effect, BioArena, formaldehyde (HCHO), immunization, overpressured layer chromatography (OPLC), ozone, quadruple bioequivalent immune system, trace elements

\section{INTRODUCTION}

Trace elements (metal ions) play an important and unique role in all living organisms and without their catalytic presence in trace or ultratrace amounts in many essential co-factors many basic biochemical reactions would not take place. ${ }^{[1-3]}$ It is known that „free" trace elements can become toxic to cells dose-dependently and they can cause damage to cellular components when their concentrations surpass certain optimal (natural) levels ${ }^{[4,5] .}$ Trace elements generate diverse biological activities and they are involved in the generation and elimination of different diseases. Although it seems that each of them has its own mechanism of action, it is believed that these mechanisms actually share common factors. ${ }^{[4,5]}$

It is already known that the possibility of the enzymatic (biological) and/or spontaneous (chemical) methylation/hydroxymethylation of trace elements means a special and unique contact between the biological and the inorganic world. ${ }^{[6,7]}$ It has to pointed out that methylated/hydroxymethylated trace elements are potential formaldehyde (HCHO) precursors (generators) and $\mathrm{HCHO}$ formed from them can participate in different endogenous reactions/interactions. ${ }^{[8,9]}$ Enzymatic transmethylation takes place through $\mathrm{HCHO}{ }^{[10]}$ and demethylation practically always involves formation of HCHO. ${ }^{[11]}$ There is a primary HCHO cycle in biological systems (Figure 3A) ${ }^{[12,13]}$ in which the formation of the S-methyl group of 
L-methionine takes place through $\mathrm{HCHO}$ originating from natural $\mathrm{HCHO}$ generators and the formation of $\mathrm{HCHO}$ from SAM is linked to trans-methylation.

It was observed that the diverse beneficial effects of trans-resveratrol (TR) as a typical stilbene derivative e.g. in grapes (wines), can originate from its double effect. ${ }^{[12,14]}$ The elimination of uncontrolled and/or controlled HCHO molecules from labile bonds in a given tissue (e.g. heart or brain tissue) with exogenous TR molecules (first step) might have a chemopreventive effect. The products of reaction between the TR and endogenous HCHO can produce a killing/inhibiting effect e.g. against pathogens or cancer cells (second step). ${ }^{[15,16]}$

It is known that some trace elements (e.g. As and Se) can be methylated enzymatically using S-adenosyl-L-methionine (SAM) as a „,methyl donor" ${ }^{\text {,[17] }}$ and spontaneously by means of $\mathrm{HCHO}$ formed/mobilized from cells/tissues. Trace elements (e.g. $\mathrm{Cu}$ and $\mathrm{Zn}$ ) can be hydroxymethylated by means of $\mathrm{HCHO}$ originating from pathogen cells or from normal tissues etc. These methylation and hydroxymethylation reactions are analogous with the first step of the above TR reaction. ${ }^{[15,16]}$ The reaction products and further products (e.g. $\mathrm{H}_{2} \mathrm{O}_{3}$, $\mathrm{O}_{3}$ ) can show the second step effect (see above) or they can participate in carcinogenesis (e.g. high dose of $\mathrm{Cu}$ coordinated with high $\mathrm{HCHO}$ level).

It follows from these observations that there are no determinative second step effects without interactions in the first step. The double effect may be the basis of diverse biological activities of trace elements. ${ }^{[18]}$ The killing/inhibiting effect of HCHO mobilized by trace elements can be further increased by means of interaction with $\mathrm{H}_{2} \mathrm{O}_{2}$. Both $\mathrm{HCHO}$ and $\mathrm{H}_{2} \mathrm{O}_{2}$ can be formed intracellularly and extracellularly by cells. These two small molecules can interact: singlet oxygen $\left({ }^{1} \mathrm{O}_{2}\right)$ and excited $\mathrm{HCHO}$ can form. ${ }^{[19,20]}{ }^{1} \mathrm{O}_{2}$ can oxidize water molecules and - among others- ozone can be formed which is an important component of the adaptive immune system (Figure 3B). ${ }^{[21-23]}$ 
According to preliminary experiments and observations trace elements as carriers transport $\mathrm{HCHO}$ molecules in a dose-dependent manner to different points of a given biological unit. ${ }^{[24]}$

The known dramatic diversity of biological activities of trace (mainly transition) elements demands a deeper knowledge and understanding about their interactions with key biological small (and big) molecules. This paper illustrates in vitro (BioArena) and in vivo (greenhouse) systems that can be used to study these reactions.

\section{EXPERIMENTAL}

\section{Experimental chemicals}

Authentic test substances (e.g. trace elements, formaline solution) were purchased from REANAL Co., Ltd. (Budapest, Hungary). All solvents and other chemicals were of analytical grade, and purchased from Merck Co., Ltd. (Darmstadt, Germany) and Reanal Co., Ltd. (Budapest, Hungary). Dye reagent: 3-[4,5-dimethylthiazol-2-yl]-2,5diphenyltetrazolium bromide (MTT) (Sigma-Aldrich Ltd., Budapest, Hungary) was used to visualize the antimicrobial activity on the adsorbent layer.

\section{Layer Liquid Chromatographic Studies}

TLC chromatoplates covered with silica gel $60 \mathrm{~F}_{254}$ (Merck, Darmstadt, Germany) and sealed at all edges were used for OPLC separation. Sample application was carried out on preconditioned $\left(3 \mathrm{~h}, 130{ }^{\circ} \mathrm{C}\right)$ adsorbent layers with a microsyringe and Linomat IV automatic sample applicator (CAMAG Co., Muttenz, Switzerland). TLC chromatograms are developed in an unsaturated chamber using different solvent systems. For OPLC separation, an automatic OPLC instrument was used, which consists of a liquid delivery system and a 
separation chamber (OPLC-NIT Co., Ltd., Budapest, Hungary). A cassette containing the chromatoplate with samples can be inserted into the chamber. After the separation process using different solvent systems, the cassette is pulled out. The dried chromatoplates were ready for densitometric and/or bioautographic evaluations. ${ }^{[25]}$ In some cases the chromatoplates had to be impregnated with $0.3 \mathrm{M} \mathrm{Na-molibdate} \mathrm{solution} \mathrm{for} \mathrm{the} \mathrm{moving} \mathrm{trace}$ elements from the start point.

\section{Biological Detection of Trace Elements on the Adsorbent Layer: the In Vitro BioArena}

\section{Studies}

For the biotest, a bacterial cell suspension of the phytopathogenic Pseudomonas savastanoi pv. phaseolicola race 6 , causing halo blight on bean, was applied. Just before use, different endogenous and/or exogenous key compounds, such as $\mathrm{HCHO}$ and $\mathrm{O}_{3}$ capture molecules, were added to aliquots of the suspension. The developed, dried chromatoplates were immersed in the bacterial suspensions [with or without (control) endogenous or exogenous compound] for $25 \mathrm{~s}$. Visualization of the bioautograms with MTT vital dye reagent was performed either after a short draining period or after an overnight incubation. ${ }^{[26,27]}$ After staining, the time for evaluation was varied from $1 \mathrm{~h}$ to a few days.

\section{In Vivo Studies: Greenhouse Experiments - Biochemical Immunization of Plants}

Chemical pre-treatment of different bean varieties was carried out by spraying the abaxial leaf surface of the plants with aqueous solutions of the inducer (+ 1 drop of TWEEN 40 in $100 \mathrm{~mL}$ solution) using decimal aqueous dilutions (ranged from $10^{-1}$ to $10^{-23} \mathrm{~mol} \mathrm{~L}^{-1}$ ). Plants treated with water were used as a control. After an induction time period of 4 days bean plants were 
spray-inoculated with an aqueous spore suspension of Uromyces phaseoli and then incubated $\left(22{ }^{\circ} \mathrm{C}, 100 \%\right.$ relative humidity) for 24 h. ${ }^{[28,29]}$ Evaluation of data was accomplished on the 9th day after inoculation. Rust pustules were counted by using a home-made pattern. Disease severity (infection rate, infectivity) was expressed as the average number of pustules on a 1 $\mathrm{cm}^{2}$ leaf area (data on the statistical evaluation on a leaf surface of a minimum of $16 \mathrm{x} 1 \mathrm{~cm}^{2}$ are needed). These values are compared with the corresponding values of control plants. The obtained relative infection rate was expressed as a percentage (control $100 \%)$. In order to study the effect of the inducer on the disease resistance of bean plants, the dependence of the infection rate on the concentration of the inducer administered (expressed in logarithmic scale) was examined ${ }^{[16,28,30]}$ The mathematical evaluation of the data was performed by moving average technique using suitable software.

(Of note, for successful experiments the chemical pre-treatment has to be carried out with an intensive washing of equipment between dilution steps with the actual dilution solution. This procedure includes a minimum of 10-15 times sprayings of next dilution solution into air or onto a indifferent surface.)

\section{RESULTS AND DISCUSSION}

\section{Short theoretical introduction to the novel experiments}

Figure 1 illustrates a modified Haraguchi ${ }^{[31]}$ schematic model of the biological world where a biological cell and biological fluid are separated by the cell membrane. Our model version includes one mechanism of action for trace elements integrating $\mathrm{HCHO}$ and its special reaction products (e.g. ${ }^{1} \mathrm{O}_{2}, \mathrm{O}_{3}$ ) as well. This ,chromatographic spot-like system” may be a home of most different biochemical pathway systems, at that time the layer chromatographic separation techniques (mainly in BioArena versions) can be used for studying them. Figure 1 
shows that the metal ions (mainly transition metals) (M) [and parallel $\mathrm{HCHO}$ molecules (F) and their reaction products] which play a fundamental role in their mechanism of action weave through the big biological units such as the genome, proteome etc. with corresponding consequences. More recently, it has been observed that the well-known antimicrobial activity of $\mathrm{Cu}$ (II) ions is indirect: the $\mathrm{Cu}$ (II) ions generate (mobilize) $\mathrm{HCHO}$ molecules from microbial cells or plant tissues and bind them forming an unknown coordination complex. This also may be a biological action (HCHO deprivation) (first step in the interaction). ${ }^{[18]}$ Figure 2 illustrates a structure of copper-hydroxymethyl complex which is a typical coordination complex of $\mathrm{Cu}$ (II) ion with a coordination number 6 forming a distorted octahedral geometry 1), while, the complex $\left[\mathrm{Cu} \cdot\left(\mathrm{CH}_{2} \mathrm{OH}\right)_{4}\right]^{+}$has a tetrahedral geometry 2) taking into account excellent work of Theophanides and Anastassopoulou ${ }^{[4]}$ with the copperammine complex. In this coordination complex from the labile hydroxymethyl groups very reactive $\mathrm{HCHO}$ can be released (second step in the double effect) ${ }^{[18]}$ with high killing/inhibiting activity to pathogen cells or to cancer cells. (It is supposed that other transition elements can generate similar hydroxymethylated derivatives in model reactions and in biological units, because all can mobilize $\mathrm{HCHO}$ molecules from microbes or other cells (tissues) in structure- and dose-dependent level. ${ }^{[18]}$ )

There is a primary HCHO cycle in biological systems (Figure 3a) ${ }^{[13,32]}$ in which the formation of the S-methyl group of L-methionine takes place through $\mathrm{HCHO}$ originating from natural $\mathrm{HCHO}$ generators (e.g. $\mathrm{N}^{5} \mathrm{CH}_{3}$ (THF)) and the formation of HCHO from S-adenosylL-methionine (SAM) is linked to trans-methylation reactions ${ }^{[10]}$ in general. HCHO cycle is a determining biochemical pathway in biological systems with unique, practically yet unknown functions. The inhibiting-killing activity of $\mathrm{HCHO}$ released can be further increased by means of interaction with an other endogenous very reactive molecule, $\mathrm{H}_{2} \mathrm{O}_{2}$. Figure $3 \mathrm{~b}$ summarizes 
the reaction series supposedly taking into account the earlier and more recent determining observations. $^{[19-23]}$ This complex figure includes two fundamental, related biochemical pathways which can be studied in BioArena system.

This study of trace elements includes the following new investigations: 1) basal reactions of trace elements with $\mathrm{HCHO}$; 2) influencing activity of trace elements for the biochemical pathways; 3) study of trace elements in in vivo conditions based on BioArena studies.

\section{Basal reactions of trace elements with $\mathrm{HCHO}$ and others in BioArena system}

It has to be pointed out that column systems (e.g. HPLC columns) are not suitable for the biological detection of trace elements or organic compounds because the living cells (e.g. bacterial cells) do not grow there, so their detection and measurement (e.g. changes) is not possible. The BioArena system provides a solution here. It integrates the advantages of layer liquid chromatographic separation (ideally linear OPLC versions ${ }^{(33,34]}$ ) and conventional and modern bioautography, ${ }^{[26,35]}$ which exploits the possibility to study interactions of cells (e.g. bacterial cells) with endogenous and exogenous small and large cofactor molecules in the adsorbent bed of the layer after separation. In these interactions $\mathrm{HCHO}$ and its reaction products (e.g. $\left.\mathrm{O}_{3}\right)$ appear as key biological molecules.

Figure 4A illustrates the antibacterial activity of $\mathrm{Cu}$ (II) ions as a well-known „old antibiotic”. When HCHO-reducing molecules (L-ascorbic acid as a strong reducing agent) are added to the culture medium (Figures 4B, 4C, 4D) this activity is characteristically (nonlinearly) reduced, in accordance with previous results. ${ }^{[27]}$ It seems that $\mathrm{Cu}$ (II) ions as old antibiotic molecules act through $\mathrm{HCHO}$ and its reaction products similar to organic antibioticlike compounds. ${ }^{[36]}$ 
Figure 5 shows that when $\mathrm{HCHO}$ molecules are added to the culture medium, the antibacterial activity is characteristically increased (more intensive spots are observable). This means at that time that the bacterial cells and culture medium do not provide enough $\mathrm{HCHO}$ molecules for the $\mathrm{Cu}$ (II) ions and shows that $\mathrm{HCHO}$ molecules participate in the antibiotic activity of $\mathrm{Cu}$ (II) ions (this is not a synergistic effect).

When natural (,classical”) HCHO-capturing molecules (reduced gluthathione and Larginine) are added to the culture medium (Figure 6B and 6C) the antibacterial activity is decreased characteristically and especially considerably in the case of reduced glutathione in accordance with previous results of organic antibiotics. $\mathrm{Cu}$ (II) ions collect the $\mathrm{HCHO}$ molecules from the bacterial cells and the culture medium to reach an antibacterial (antibiotic) effect. $^{[27,36]}$

\section{Influence of trace elements on the biochemical pathways}

Figure 7 shows the antibacterial activity of trans-resveratrol (TR) in the presence of Fe (III), Zn (II), and Mn (II) ions. These metal ions generated a bigger activity than the control in all cases, that is, they gave more $\mathrm{HCHO}$ molecules to effect of TR. The $\mathrm{Cu}$ (II) ions generated bigger effect than these trace elements. ${ }^{[37]}$ It is obvious that the intensity of the first step (HCHO deprivation) depends on the trace element structure and dose but without this first step there is not a possibility for second step (killing/inhibiting effect). Importantly, trace elements generate double effect similar e.g. to TR. ${ }^{[15,16]}$

In the presence of mycotoxins (e.g. aflatoxins) the $\mathrm{HCHO}$ level in a given biological unit is elevated by advanced liberation from bounded forms (e.g. because of the stress situation $)^{[13]}$ and it may form from themselves aflatoxins by demethylation reaction. ${ }^{[29]}$ The elimination of $\mathrm{HCHO}$ from the system (e.g. chromatographic spots) can decrease the antimicrobial-toxic 
effect of mycotoxins. ${ }^{[38,39]}$ Figure 8 illustrates the change of B1 aflatoxin antibacterial activity in the presence of different doses of Se (IV). It can be seen that increasing the amount of Se (IV) ion in the culture medium the antibacterial activity of aflatoxin B1 decreases dramatically. Meanwhile it has been established that $\mathrm{Cu}$ (II) and Se (IV) ions generate opposite effect on the antibacterial-toxic action of mycotoxins. ${ }^{[40]}$

It is known that trans-resveratrol (TR) is a natural, concentration-dependent $\mathrm{HCHO}$ mobilizer, scavanger, capture and carrier molecule. ${ }^{[15,16]}$ It is interesting that in the presence of $\mathrm{Cu}$ (II) ions the antibacterial activity of TR considerably increases. ${ }^{[27,36]}$ This is valid for other transition elements as it can be seen on Figure 7. Figure 9 illustrates the effect of cobalt (Co (II)) ions on the antibacterial effect of TR. It was probable that this transition element will also increase the antibacterial activity of TR, however, it seems that it acts perceptibly for the separation of two TR isomers as well. These results show clearly that the separation and observation possibilities are unlimited in BioArena system.

Ochratoxin A (OA) kills the pathogenic bacterial cells by endogenous ozone $\left(\mathrm{O}_{3}\right) .^{[27,36,41]}$ Figure 3B shows the formation possibilities of endogenous $\mathrm{O}_{3}$ practically from the interaction of $\mathrm{HCHO}$ with $\mathrm{H}_{2} \mathrm{O}_{2} \cdot{ }^{[19-23]}$ Using $\mathrm{Cu}$ (II) ions in the culture medium the antibacterial activity of OA increases (Figure 10.) supposedly on the basis of reaction series demonstrated in Figure 3B. (HCHO is an $\mathrm{O}_{3}$ precursor in this case).

\section{Extension of in vitro (BioArena) results with trace elements for in vivo conditions (greenhouse investigations)}

According to our preliminary investigations in vitro (BioArena - layer chromatography) results with trace elements can also be used in in vivo conditions $[18,28,42]$ as in the case of organic compounds. ${ }^{[16,28,30]}$ Figure 11 illustrates the quadruple, bioequivalent(four equal 
immune-stimulating ranges), non-linear, specific (time- and dose dependent) immune response effect of bean plants for the pre-treatment with different doses of $\mathrm{Ni}$ (II) ion. These results support the preliminary results with the $\mathrm{CU}$ (II) and $\mathrm{Ni}$ (II) ions as inorganic inducers. ${ }^{[42]}$ Using a $\mathrm{HCHO}$ capture molecule in vivo (e.g. dimedone), the four active immune response ranges of the bean plants could be eliminated, ${ }^{[42]}$ similar to the elimination of the antibiotic effect in the in vitro (BioArena) studies on the adsorbent layer. ${ }^{[27]}$ In fact the quadruple immune response of plants can analogously be induced by other trace elements. The possibilities are unlimited.

Figure 11 illustrates clearly that $\mathrm{Ni}(\mathrm{II})$ ions can also generate negative arm of hormesis effect $(-\log c=1)($ retardation/destruction) and at that time the positive arm of the hormesis (immune-stimulating effect at $-\log \mathrm{c}=5$ ) as well. ${ }^{[42]}$

\section{CONCLUSIONS}

The layer liquid system is suitable only for the biological detection and interactions, and development of BioArena provides unlimited possibilities for studying fundamental biochemical mechanisms. These possibilities ensure also the future of the layer liquid chromatographic techniques.

These results with trace elements (metal ions) challenge also the idea on the two-phase hormesis ${ }^{[43,44]}$ and show that hormesis phases are in the resistance phase of the stress syndrome. ${ }^{[45]}$ It seems on the basis of quadruple immune response of plants to pathogens that the resistance phase of stress syndrome ${ }^{[45]}$ can be divided into four equivalent parts.

Further study of trace elements (mainly transition metal ions) in vitro (in BioArena) and in vivo (e.g.in greenhouse) conditions regarding to $\mathrm{HCHO} / \mathrm{O}_{3}$ idea promises further 
surprising results -among others - in the field of hormesis and resistance.

It follows also from these results that dosing will occupy more important role in our life in future than in earlier times. The quadruple, bioequivalent, non-linear, specific immune response system (also for trace elements) opens new horizons, and we are only at the beginning to understand this unique finding.

\section{ACKNOWLEDGMENT}

The authors gratefully acknowledge the chemical, biochemical and microbiological technical help of Mrs. Edit Dobos-Harsányi.

\section{REFERENCES}

1. Aposhian, H.V.; Zakharyan, R.A.; Avram, M.D.; Sampayo-Reyes, A.; Wollenberg, M.L. A review of the enzymology of arsenic metabolism and a new potential role of hydrogen peroxide in the detoxification of the trivalent arsenic species. Toxicol. Appl. Pharmacol. 2004, 198, 327-335.

2. Hutcheson, R.U.; Broderick, J.B. Radical SAM enzymes in methylation and methylthiolation. Metallomics 2012, 4, 1149-1154.

3. Trantini, L.; Bonzini, M.; Tripodi, A.; Angelici, L.; Nordio, F.; Cantone, L.;Apostoli, P.; Bertazzi, P.A.; Baccarelli, A.A. Blood hypomethylation of inflammatory genes mediates the effects of metal-rich airborne pollutants on blood coagulation. Occup. Environ. Med. 2013, 70, 418-425.

4. Theophanides, T.; Anastassopoulou, J. Copper and carcinogenesis. Crit Rev. Toxicol. Hematol.2002,42, 57-64.

5. Purchase, R. The link between copper and Wilson's disease. Sci. Prog. 2013, $96,213-223$. 
6. Rech, M.; To, L.; Tovbin, A.; Smoot, T.; Mlynarek, M. Heavy metal in the ICU: A review of current literature on trace element supplementation in critically ill patients. Nutr. Clin. Pract. 2013, Dec. $12 .$.

7. Yang, L.; Pascal, M.; Wu, X.H. Review of selenium and prostate cancer prevention. Asian Pac. J. Cancer Prev. 2013, 14, 181-184.

8. Zhou, X.; Li, Q.; Arita, A.; Sun, H.; Costa, M. Effects of nickel, chromate and arsenite on histone 3 lysine methylation. Toxicol. Appl. Pharmacol. 2009, 236, 78-84.

9. Tschou-Wong, K-M.; Kiok, K.; Tang, Z.; Kluz, T.; Arita, A.; Smith, P.R.; Brown, S.; Costa, M. Effect of nickel treatment on H3K4 trimethylation and gene expression. PLoS ONE 2011, 6, e17728.

10. Huszti, S.; Tyihák, E. Formation of formaldehyde from S-adenosyl-Lmethionine during enzymic transmethylation of histamine. FEBS Lett. 1986, 209, 362-366.

11. Kalász, H.; Báthori, M.; Tyihák, E. Formaldehyde generation by $\mathrm{N}$ demethylation. Acta Biol. Hung. 1998, 49, 339-344.

12. Tyihák, E.; Albert, L.; Németh, Zs.I.; Kátay, Gy.; Király-Véghely, Zs.;

Szende, B. Formaldehyde cycle and the natural formaldehyde generators and capturers. Acta Biol. Hung. 1998, 49, 225-238.

13, Tyihák, E.; Trézl, L.; Szende, B. Formaldehyde cycle and the phases stress syndrome. Ann. N. Y. Acad. Sci. 1998, 851, 259-270.

14. Tyihák, E.; Kátay, Gy.; Király-Véghely, Zs.; Németh, Zs.; Albert, L.; Szende, B.; Vitis vinifera as a medicinal plant. Acta Hort. 2003, 597, 159-165. 
15. Tyihák, E.; Király-Véghely, Zs. Interaction of trans-resveratrol with endogenous formaldehyde as one basis of its diverse beneficial biological effects. Bulletin de l'OIV. 2008, 81, 65-74.

16. Tyihák, E.; Király-Véghely, Zs.; Móricz, Á.M. Multiple beneficial effects of resveratrol and their chemical-biochemical basis. Nat. Prod. Commun. 2011, 6, 631-638.

17. Whanger, P.D. Selenocompunds in plants and animals and their biological significance. J. Am. Coll. Nutr. 2002, 21, 223-232.

18. Tyihák, E.; Móricz, Á.M.; Ott, P.G.; Király-Véghely, Zs.; Kátay, Gy. In: Procs.Intern. Symp. on Trace Elements in the Food Chain. Budapest, May 25-27, 2006. (Eds: Szilágyi, M., Szentmihályi, K.) pp. 394-399.

19. Trézl, L., Pipek, J. Formation of excited formaldehyde in model reactions simulating real biological systems. J. Mol. Struc. - Theochem. 1988, 170, 213-223.

20. Tyihák, E.; Rozsnyay, S.; Sárdi, É.; Gullner, G.; Trézl, L.; Gáborjányi, R. Possibility of formation of excited formaldehyde and singlet oxygen in biotic and abiotic stress situations. Acta Biol. Hung. 1994, 45, 3-10.

21. Wentworth. P. Jr.; McDunn, J.E.; Wentworth, A.D.; Takeuchi, C.; Nieva, J.; Jones, T.; Bautista, C.; Ruedi, J.M.; Gutierrez, A.; Janda, K.D.; Babior, B.M.; Eschenmoser, A.; Lerner, R.A. Evidence for antibody-catalyzed ozone formation in bacterial killing and inflammation. Science 2002, 298, 2195-2199.

22. Wentworth, P.Jr.; Wentworth, A.D.; Zhu, X.; Wilson, I.A.; Janda, K.D.;

Eschenmoser, A.; Lerner, R.A. Evidence for the production of trioxygen species during antibody-catalyzed chemical modification of antigens. Proc.

Natl. Acad. Sci. USA 2003, 100, 1490-1493. 
23. Babior, B.M.; Takeuchi, C.;Ruedi,J.; Gutierrez, A.; Wentworth, P.Jr. Investigating antibody-catalyzed ozone generation by human neutrophils. Proc. Natl. Acad.Sci. USA 2003, 100, 3031-3034.

.24. . Tyihák, E.; Takátsy, A.; Móricz, Á.M.; Ott, P.G.; Ohmacht, R. In: Trace

Elements in the Food Chain. Vol. 3. Deficiency or Excess of Trace

Elements in the Environment as a Risk of Health. Budapest, Hungary,

(eds: Szilágyi, M.; Szentmihályi, K.), 2009, pp. 392-396.

25, Tyihák, E.; Mincsovics, E.; Móricz, Á.M. Overpressured layer chromatography:From the pressurized ultramicro chamber to BioArena system. J. Chromatogr. A, 2012, 1232, 3-18.

26. Móricz, Á.M.; Adányi, N.; Horváth, E.; Ott, P.G.; Tyihák, E. Applicability of the BioArena system to investigation of the mechanisms of biological effects. J. Planar Chromatogr. 2008, 21, 417-422.

27. Tyihák, E.; Móricz, Á.M.; Ott, P.G.; Király-Véghely, Zs.; Kátay, Gy.; Mincsovics, E. BioArena system for knowing and understanding the biological world: A review with new experimental results. J. AOAC. Int. 2013, 96, 1189-1199

28. Tyihák, E. In: Teixeira da Silva, J.A. (ed.) Foliculture, Oriental and Plant Biotechnology, Advances and Topical Issues, Vol.3, Ch. 40: Double immune response of plants to pathogens and its biochemical basis. Global Science Books, London, 2006.

29. Móricz, Á.M.; Otta, K.-H.; Ott, P.G.; Tyihák, E. Separation and detection oaflatoxins using overpressured layer chromatography and bioautography. J. Planar Chromatogr. 2003, 16, 417-42

30. Tyihák, E.; Mincsovics, E. Forced-flow planar liquid chromatographic techniques (After twenty-two years). J. Planar Chromatogr. 2010, 23, 382-395 
31. Haraguchi, H. Metallomics as integrated biometal science. J. Anal. Atom. Spectrom. 2004, 19, 5-14

32. Tyihák, E. Overpressured layer chromatographic methods in the study of the formaldehyde cycle in biological systems. TRAC- Trends in Anal.. Chem. $1987,6,90-94$

33. Tyihák,E.; Mincsovics, E. In: Nyiredy, Sz. (ed.), Planar Chromatography. A Retrospective View for the Third Millenniumm, Springer, Budapest,2001, pp. 193-213.

34. Mincsovics, E.; Ferenczi-Fodor, K.; Tyihák, E. Overpressured Layer Chromatography, In: Sherma, J. , Fried, B., (eds.), Marcel-Dekker, New York, NY, 2003, 171-203.

35. Goodall, R.R.; Levi, A.A. A microchromatographic method for the detection and approximate determination of the different penicillins in a mixture. Nature, 1946, 158, 675-676.

36. Tyihák, E.; Móricz, Á.M.; Ott, P. BioArena studies: Unique function of endogenous formaldehyde and ozone in the antibiotic effect.- A review. Med. Chem. 2012, 8, 75-84.

37. Tyihák, E.; Móricz, Á.M.; Ott, P.G. Role of formaldehydome in antibiotic effect: new approach to mechanism of antibiotic action of some metal ions. In: Metal lons in Biology and Medicine. Cser, M.A. et al. (eds.), John Libbey Eurotext, Paris, 2004, vol. 8, pp. 131-134.

38. Móricz, Á.M.; Ott, P.G.; Billes, F.; Otta, K-H.; Tyihák, E. The influence of L-ascorbic acid on the antibacterial-toxic activity of aflatoxins on adsorbent layer. J. Appl. Microbiol. 2007, 103, 2525-2532.

39. Móricz, Á.M. Dissertation. Eötvös L. University, Budapest, Hungary. 
40. Móricz, Á.M.; Ott, P.G.; Szilágyi, M.; Otta, K-H.; Tyihák, E. Opposite effect of $\mathrm{Cu}$ (II) and Se (IV) ions on the antibacterial-toxic action of mycotoxins. Acta Biol. Hung. 2007, 58, 301-310.

41. Tyihák, E.; Mincsovics, E.; Kátay, Gy., Király-Véghely, Zs.; Móricz, Á.M., Ott, P.G. BioArena: an unlimited possibility of biochemical interactions in the adsorbent layer after chromatographic separation. J. Planar Chromatogr. 2008, 21, 15-20.

42. Tyihák, E.; Móricz, Á.M.; Szilágyi, M; Billes, F. Quadruple immune response of plants to pathogens after pretreatment with different doses of trace elements. Eur. Chem. Bull. 2012, 1, 528-530.

43. Calabrese, E.J. Hormetic mechanisms. Arch. Toxicol. 2013, 87, 1621-1633.

44 Calabrese, E.J. Hormesis and medicine. Br. J. Clin. Pharmacol. 2008, 66, 594-617.

45. Selye, H. The Stress of Life. McGraw-Hill Book Co., Inc. New York, NY, 1956, pp. 1-324.

\section{Captions to figures of Tyihák E. et al.: JLC\&RT, 2014.}

Figure 1. A schematic model of the biological world in ,,a chromatographic spot” using a modified Haraguchi model [31] with special emphasis on the unique role of $\mathrm{HCHO} / \mathrm{O}_{3}$ idea in the mechanism of action supposed of trace elements (metal ions). 
Figure 2. The potential structure of the copper- $\mathrm{CH}_{2} \mathrm{OH}$ complex.

1) Octahedral geometry; 2) tetrahedral geometry $[4,24]$.

Figure 3. Joining two fundamental biochemical pathways: formaldehyde cycle $[12,13,32]$

(A) and generation of key oxidants from the interaction of $\mathrm{HCHO}$ and $\mathrm{H}_{2} \mathrm{O}_{2}$ $[27,28,36](B)$.

Figure 4. Effect of L-ascorbic acid (AA) as reducing agent on the antibacterial effect of $\mathrm{Cu}$ (II) ions against Pseudomonas savastanoi pv. phaseolicola (Psm).

A: layer dipped into Psm cell suspension, control; B-D: 10, 50 and 100 mg AA in $100 \mathrm{~mL}$ cell suspension; Chromatographic conditions:chromatoplate : silica gel $60 \mathrm{~F}_{254}$ (Merck) impregnated by $0.3 \mathrm{M}$ Na-molibdate, drying; then preconditioning at $130^{\circ} \mathrm{C}$ for $3 \mathrm{~h}$. sample application; eluent: $1 \mathrm{M} \mathrm{Na-formate} \mathrm{(rechromatography);}$ Detection (visualization) was performed with MTT (methyl thiazolyl tetrazolium chloride).

Figure 5. Effect of $\mathrm{HCHO}$ aqueous solution administration on the antibacterial activity of $\mathrm{Cu}(\mathrm{II})$ ions against Pseudomonas savastanoi pv. phaseolicola (Psm). Chromatographic conditions: silica gel $60 \mathrm{~F}_{254}$ (Merck), preconditioning at $\mathbf{1 3 0}^{\circ}$ for $3 \mathrm{~h}$. Mobile phase: $0.1 \mathrm{M} \mathrm{Na}$-formate. Visualization was performed with MTT. The real control is the diluted formalin solution alone (third sheet). Spots were not observable there, but dramatic spots were observable in the copper and formaline solution on the second sheet. 
Figure 6. Effect of natural $\mathrm{HCHO}$ capturers on the antibacterial activity of $\mathrm{Cu}$ (II) ions against Pseudomonas savastanoi pv. phaseolicola (Psm). Chromatographic conditions: silica gel $60 \mathrm{~F}_{254}$ (Merck); preconditioning at $130^{\circ}$ for 3 h. mobile phase: $1 \mathrm{M}$ formate; visualization with MTT.

Figure 7. Effect of different trace elements on the antibacterial activity of transresveratrol.

A: Pseudomonas savastanoi pv. phaseolicola, alone, control, Psm; B: + 1 $\mathrm{mg} / \mathrm{mL} \quad \mathrm{FeCl}_{3} \cdot 6 \mathrm{H}_{2} \mathrm{O} ; \quad \mathrm{C}:+1 \mathrm{mg} / \mathrm{mL} \mathrm{MnCl}_{2} \cdot 4 \mathrm{H}_{2} \mathrm{O} ; \mathrm{D}:+1 \mathrm{mg} / \mathrm{mL} \mathrm{ZnSO}_{4}$ 7 $\mathrm{H}_{2} \mathrm{O}$. Chromatographic conditions: chromatoplate: silica gel 60F 254 (Merck, preconditioning at $12{ }^{\circ} \mathrm{C}$ for $3 \mathrm{~h}$ ); mobile phase: chloroform-methanol, 80:8, (v/v); Incubation time between inoculation and staining was $2 \mathrm{~h}$. This picture was taken $18 \mathrm{~h}$ after staining.

Figure 8. Effect of Se(IV) ions on the antibacterial activity of aflatoxin B1.

A: Pseudomonas savastanoi pv. phaseolicola, alone, control;

B-E: $+0.01,0.1,1$ and $2 \mathrm{mg}$ sodium selenite in $100 \mathrm{~mL}$ cell

suspension. Chromatographic conditions: chromatoplate: silica gel $60 \mathrm{~F}_{254}$ (Merck, preconditioning at $120^{\circ} \mathrm{C}$ for $3 \mathrm{~h}$; mobile phase: chloroform-acetone, 9:1 (v/v); Detection at the end of the process with MTT. 
Figure 9. Effect of cobalt (II) ions on the antibacterial activity of trans-resveratrol. A: Psm, Pseudomonas savastanoi pv. phaseolicola cell suspension, alone, control; B-D: $+2,4$ and $6 \mathrm{mg} \mathrm{CoCl}_{3}$ in $100 \mathrm{~mL}$ cell suspension Chromatographic conditions: silica gel $60 \mathrm{~F}_{254}$ (Merck). Preconditioning at $130{ }^{\circ} \mathrm{C}$ for 3 h.Mobile phase: chloroform-methanol 80:8 (v/v) Visualization with MTT.

Figure 10. Effect of $\mathrm{Cu}(\mathrm{II})$ ions on the antibacterial activity of ochratoxin $\mathrm{A}$. A: Psm, Pseudomonas savastanoi pv. phaseolicola cell suspension, alone, control; B and C: 4 and $6 \mathrm{mg} \mathrm{CuSO}_{4} \times 5 \mathrm{H}_{2} \mathrm{O}$ in $100 \mathrm{~mL}$ cell suspension Chromatographic conditions: silica gel $60 \mathrm{~F}_{254}$ (Merck). Preconditioning at $130^{\circ} \mathrm{C}$ for $3 \mathrm{~h}$. Mobile phase: chloroform-methanol, 8:2 (v/v). Visualization with MTT.

(Copper ion was the $\mathrm{HCHO}$ carrier and $\mathrm{OA}$ is a $\mathrm{HCHO}$ acceptor molecule on the basis of its structure.)

Figure 11. Effect of $\mathrm{Ni}$ (II) ion as inorganic inducer on the disease resistance of bean plants to bean rust (Uromyces phaseoli) using decimal dilution. Bean plants are inoculated with an aqueous spore suspension of bean rust 4 days after pre-treatment with the doses of inorganic inducer.(Ni (II) ion is a HCHO carrier!)

(This figure is a demonstration of quadruple, bioequivalent, non-linear, specific immune response system of plants). (Induced resistance) 
Figures to JLC \&RT, Tyihák E. et al. (2014)

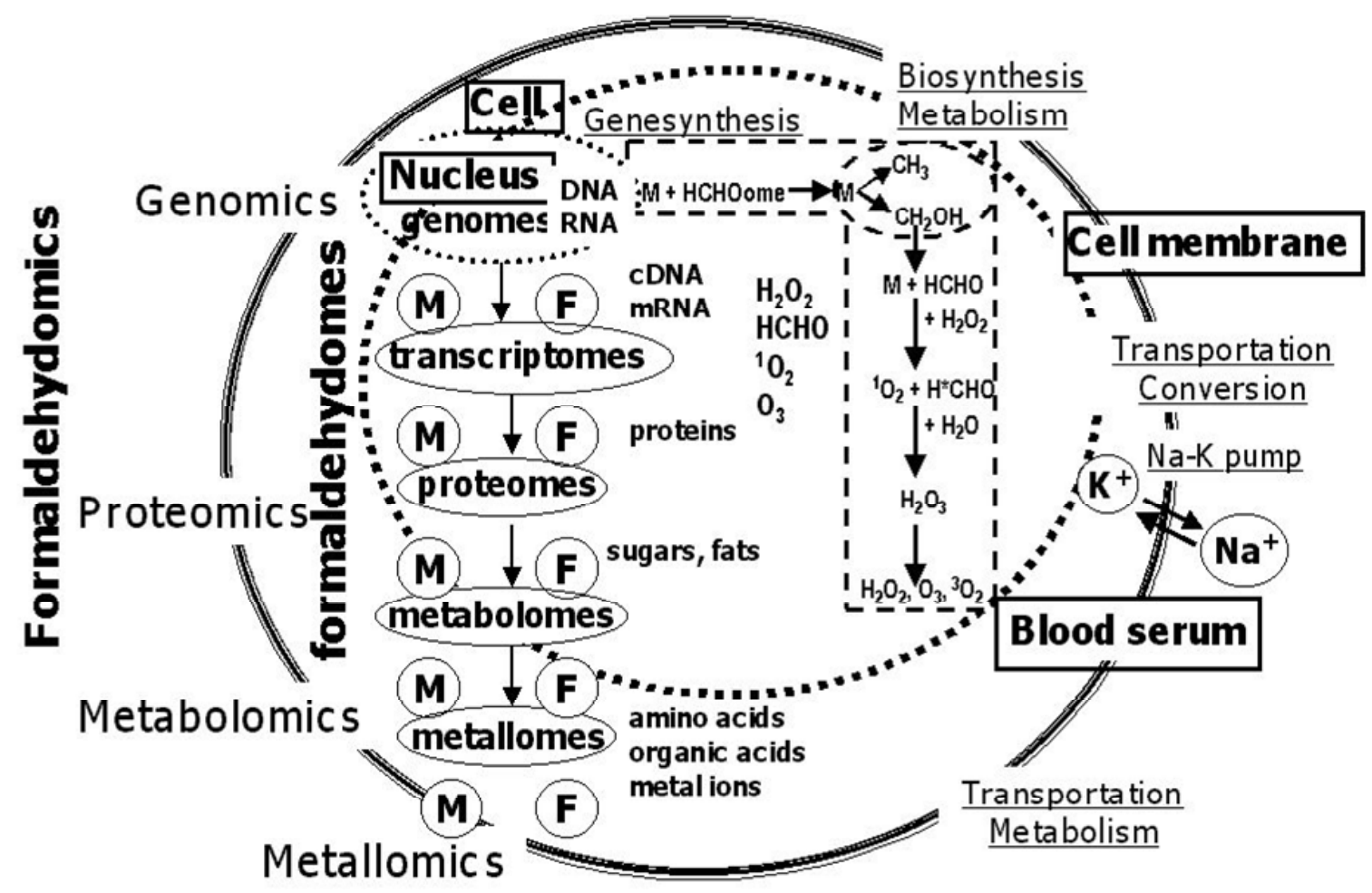

Figure 1<smiles>OCC(O)(CO)C(O)(CO)CO</smiles>

1)<smiles>OCC(CO)(CO)CO</smiles>

2)

Figure 2 


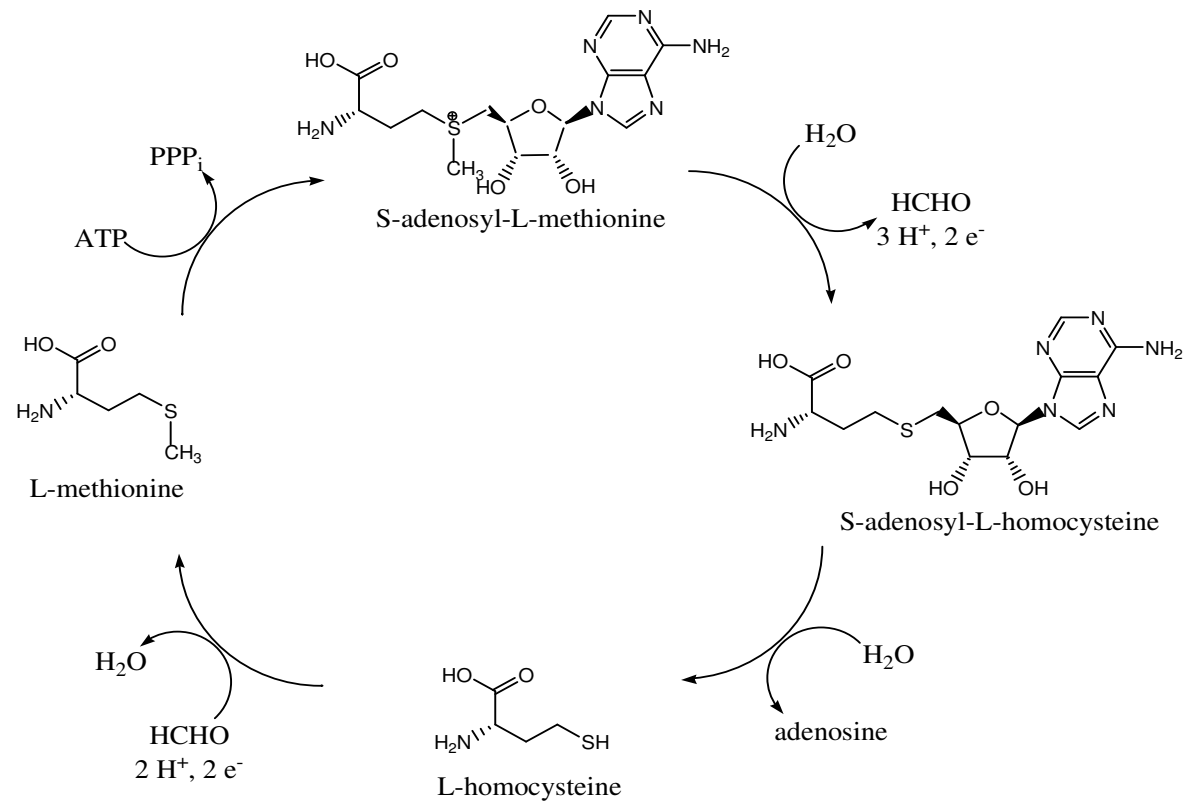

A) $\mathrm{HCHO}$ cycle

through the formaldehydome system

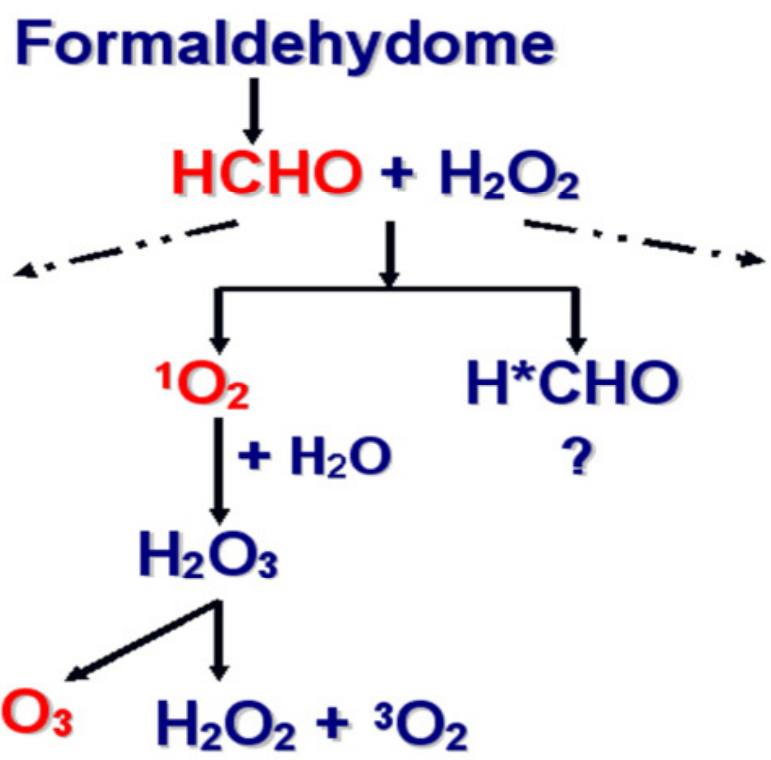

B) Simplified reaction scheme of reactive oxidants

Figure 3 
A

B
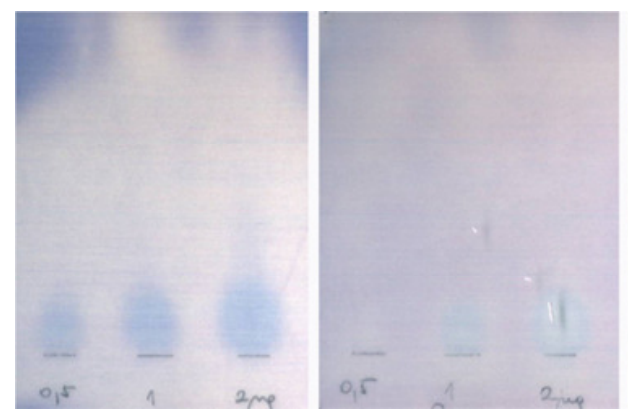

0.5, 1.0 and 2.0 ug $\mathrm{CuSO}_{4} .5 \mathrm{H}_{2} \mathrm{O}$ (in all four cases)
D
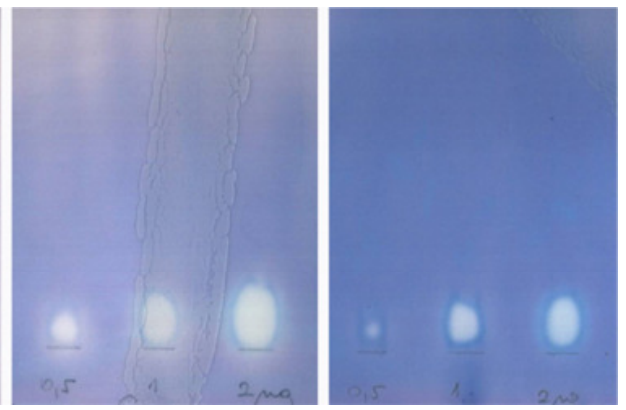

Figure 4
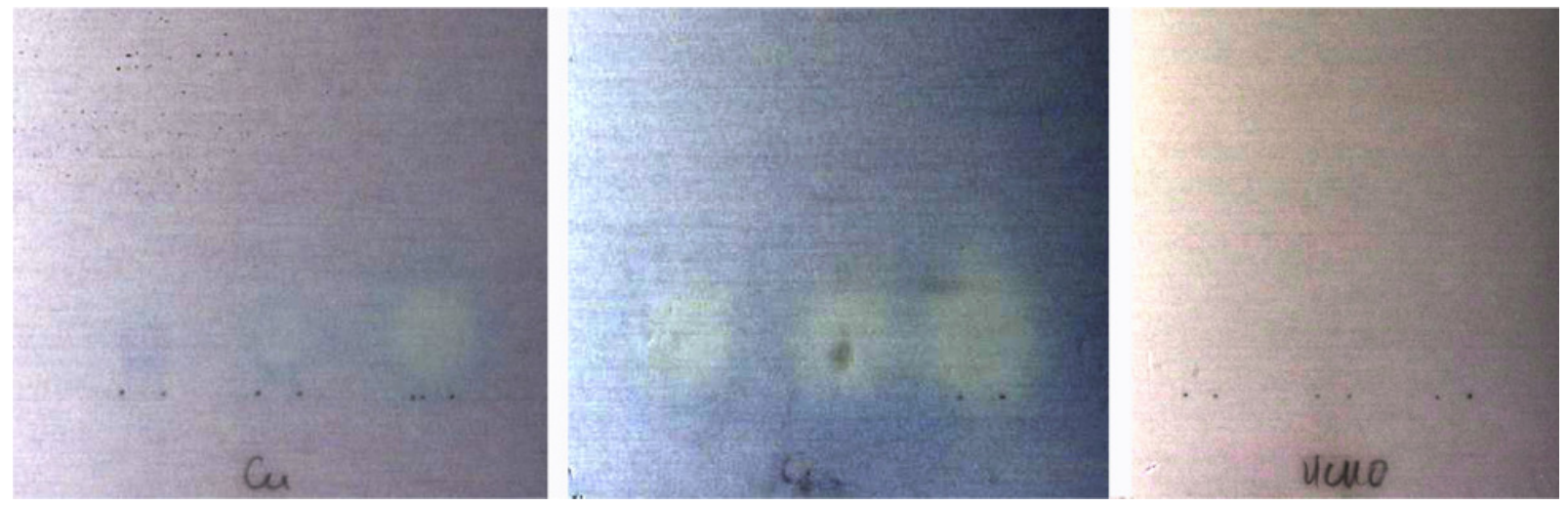

1,2 and $4 \mathrm{uL}$ of $1 \mathrm{mg} / \mathrm{mL}$

$\mathrm{CuSO}_{4} \cdot 5 \mathrm{H}_{2} \mathrm{O}$

dissolved in distilled water
1,2 and $4 \mathrm{uL}$ of $1 \mathrm{mg} / \mathrm{mL}$

$\mathrm{CuSO}_{4} \cdot 5 \mathrm{H}_{2} \mathrm{O}$
1,2 and 4 uL of

$0.316 \mathrm{M}$ formalin

dissolved in $0.316 \mathrm{M}$ formalin

Figure 5 
A

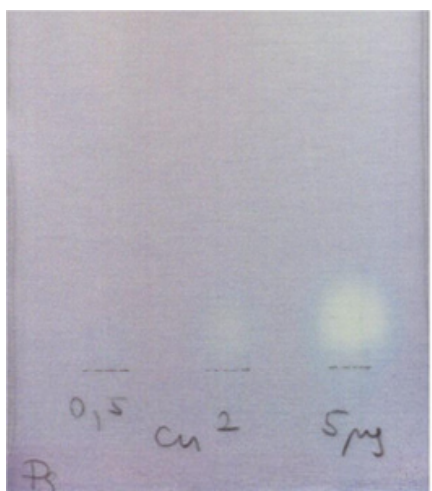

B

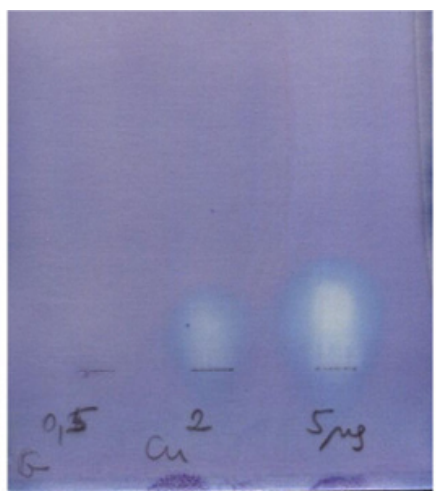

C

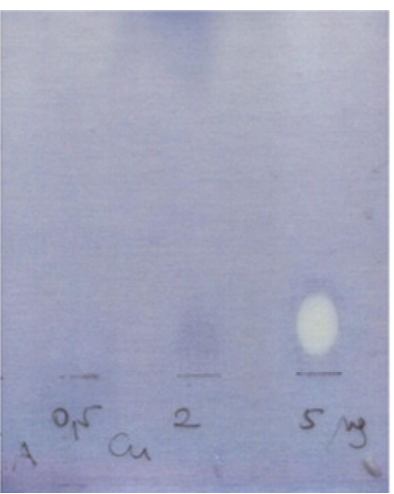

0.5, 2.0 and $5 \mu \mathrm{CuSO}_{4} .5 \mathrm{H}_{2} \mathrm{O}$ (in all three cases)

\section{Figure 6}

A

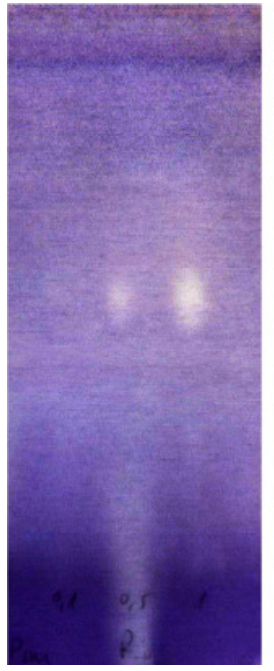

B

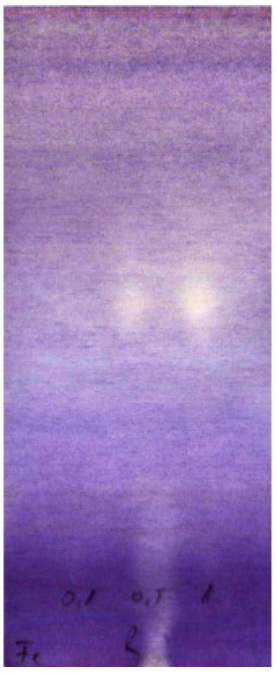

C

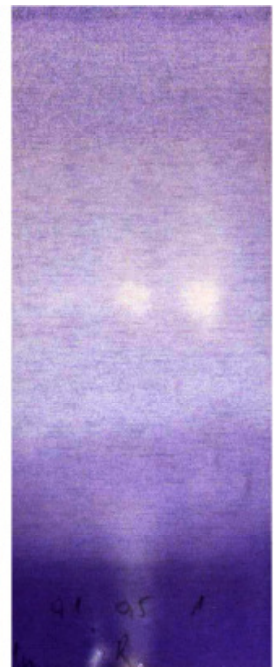

D

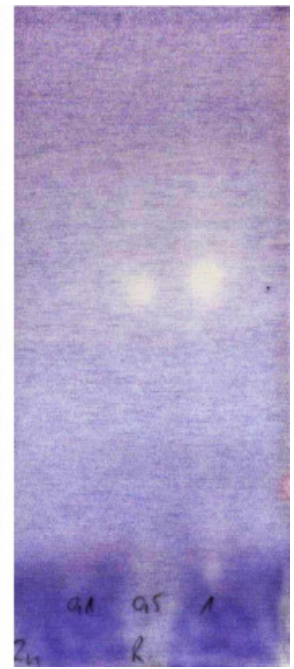

$0.1,0.5$ and 1 ug trans-resveratrol (in all four cases)

Figure 7 


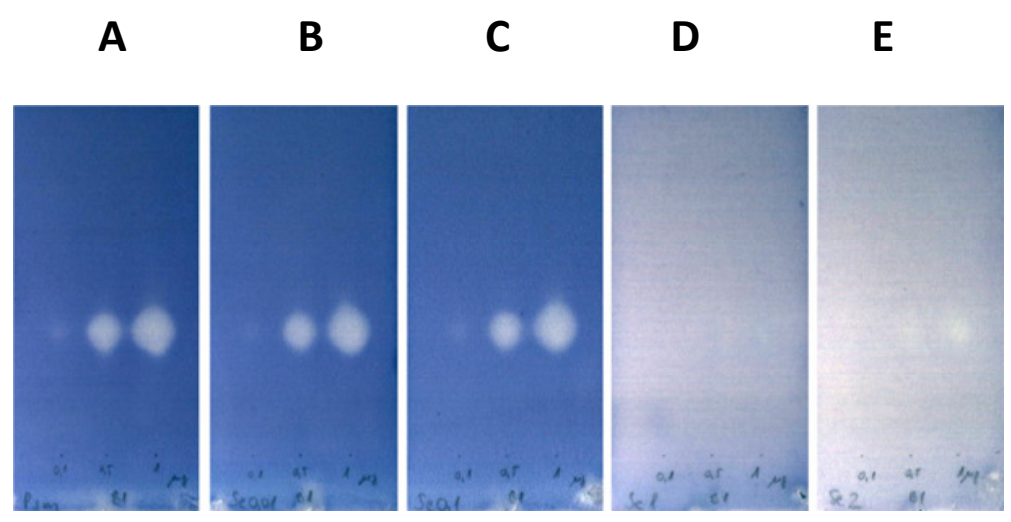

$0.1,0.5$ and $1.0 \mu \mathrm{g}$ aflatoxin B1 (in all five cases)

Figure 8

A

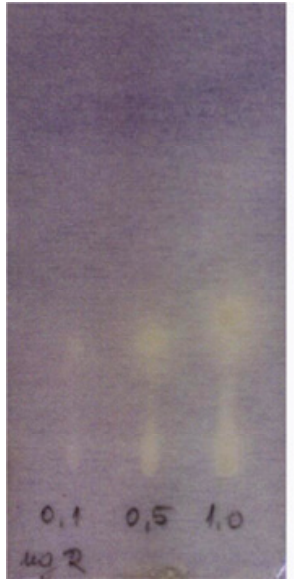

B

C

D
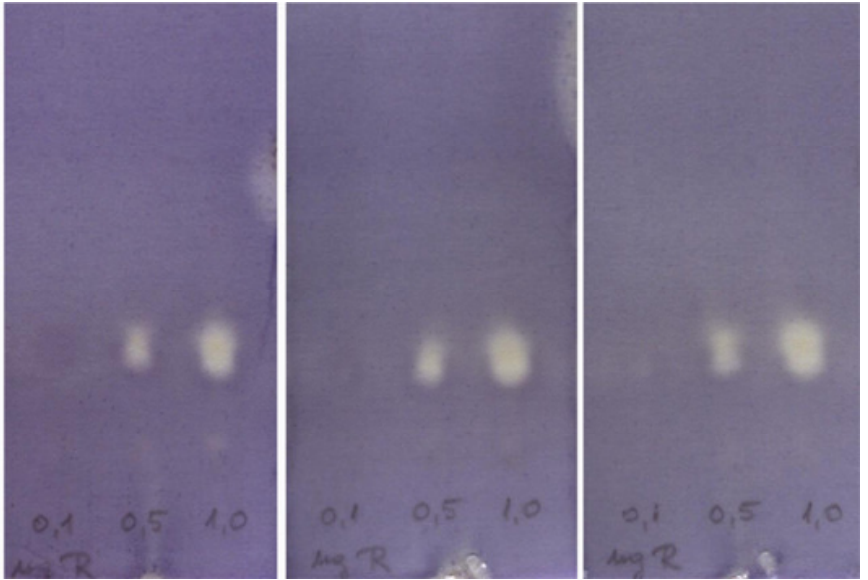

$0.1,0.5$ and $1.0 \mu \mathrm{g}$ trans-resveratrol (in all four cases)

Figure 9 
A
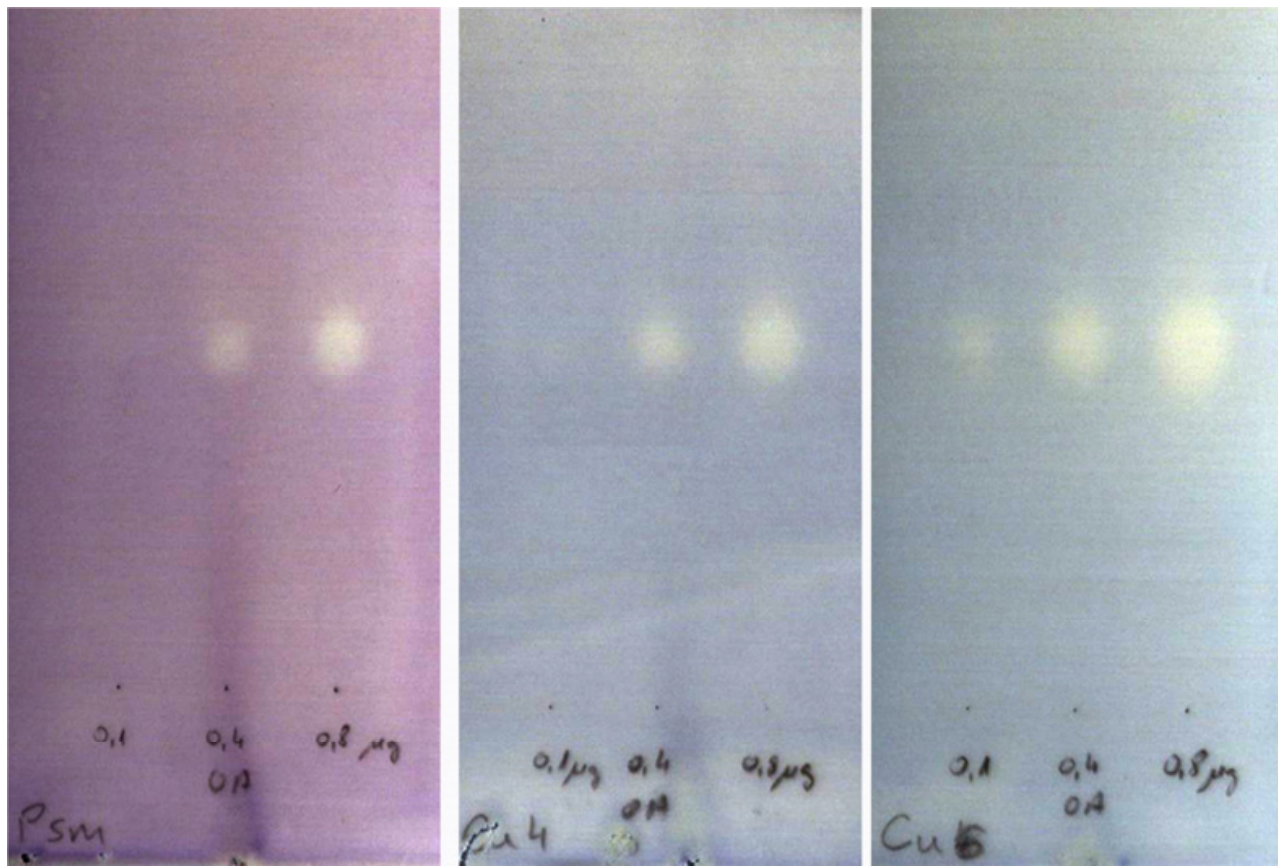

$0.1,0.2$ and $0.8 \mu \mathrm{g}$ ochratoxin A (in all three cases)

Figure 10

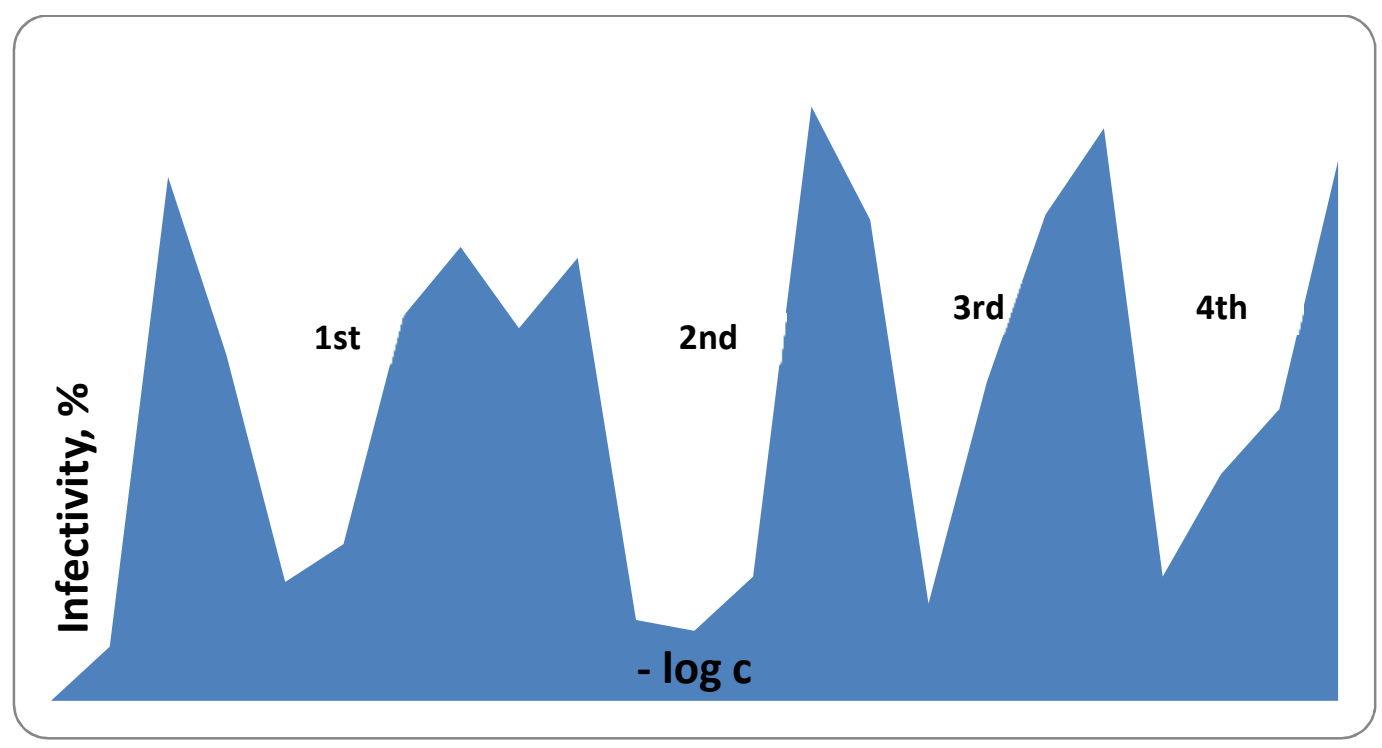

Figure 11

B

C 